\title{
Surviving Extreme Anaemia
}

\author{
$\underline{\text { Joana M Esteves }}^{1}$, Joana Fernandes ${ }^{2}$, Pedro Oliveira Monteiro ${ }^{3}$, Mariana Almeida ${ }^{4}$, Luis Nogueira-Silva ${ }^{4,5,6}$, Jorge Almeidaa \\ ${ }^{1}$ Internal Medicine Department, Hospital Santa Maria Maior, Barcelos, Portugal \\ ${ }^{2}$ Intensive Care Medicine Department, Centro Hospitalar e Universitário São João, Porto, Portugal \\ ${ }^{3}$ Clinical Hematology Department, Centro Hospitalar e Universitário São João, Porto, Portugal \\ ${ }^{4}$ Internal Medicine Department, Centro Hospitalar e Universitário São João, Porto, Portugal \\ ${ }^{5}$ Center for Research in Health Technologies and Information Systems (CINTESIS), Faculty of Medicine, University of Porto, Porto, Portugal \\ ${ }^{6}$ Medicine Department, Faculty of Medicine, University of Porto, Porto, Portugal
}

\section{Doi: 10.12890/2021_002357 - European Journal of Case Reports in Internal Medicine - @ EFIM 2021}

Received: 03/02/2021

Accepted: 08/02/2021

Published: 05/03/2021

How to cite this article: Esteves ME, Fernandes J, Oliveira Monteiro P, Almeida M, Nogueira-Silva L, Almeida J. Surviving extreme anaemia. EJCRIM 2021;8: doi:10.12890/2020_002357.

Conflicts of Interests: The Authors declare that there are no competing interests.

This article is licensed under a Commons Attribution Non-Commercial 4.0 License

\section{ABSTRACT}

Before the development of transfusion medicine, severe anaemia was an important cause of morbidity and mortality. The discovery of haematopoietic mechanisms and essential nutrients made it possible to easily treat and prevent this condition. Nevertheless, it is often fatal in patients presenting with extreme anaemia (haemoglobin levels $<2 \mathrm{~g} / \mathrm{dl}$ ). We report the rare case of a 54-year-old woman who presented with profound megaloblastic anaemia (haemoglobin of $1.7 \mathrm{~g} / \mathrm{dl}$ ) due to vitamin B12 deficiency, and was successfully treated.

\section{LEARNING POINTS}

- The discovery of vitamin B12 in the 20th century led to the successful and easy treatment of thousands of patients with anaemia.

- Focus on patient adherence to treatment and medical advice is essential in order to manage chronic conditions such as post-gastrectomy nutritional deficiencies.

- Extreme anaemia is very rare and associated with high mortality; treatment should be tailored to acute or chronic anaemia and in cases where haemodynamic stability is guaranteed, a restrictive blood transfusion strategy should be considered to reduce the risk of complications.

\section{KEYWORDS}

Severe anaemia, vitamin B12, nutritional deficiency

\section{INTRODUCTION}

Active blood loss is usually the main concern when extreme anaemia is found: significant acute-onset bleeding without proper management can develop into haemorrhagic shock and death. Other more insidious disorders, such as cancers, infections, malnutrition, and haemopoietic or drug-induced conditions, can also cause severe anaemia. Increased cardiac output, decreased peripheral vascular resistance, and decreased oxygen affinity of red blood cells (RBC) are some of the physiological changes that occur in response to anaemia, and patients will develop dyspnoea, easy fatigue, or tachycardia on exertion, and usually resort to healthcare before haemoglobin levels start to plummet. When a restrictive blood transfusion strategy is implemented, moderate anaemia (haemoglobin ( $\mathrm{Hb}$ ) of 7-10 g/dl) is not associated with increased mortality ${ }^{[1]}$. In patients without major haemorrhage, chronic anaemia or acute coronary syndrome, the Hb level threshold for RBC transfusion is currently $7 \mathrm{~g} / \mathrm{dl}^{[2,3]}$, as morbidity and mortality increases when $\mathrm{Hb}$ levels are below $7 \mathrm{~g} / \mathrm{dl}$. Carson et al. ${ }^{[4]}$ retrospectively 
studied the relationship between the nadir of postoperative $\mathrm{Hb}$ levels and mortality, in 300 patients who refused blood transfusions, and showed that the 30-day mortality for $\mathrm{Hb}$ of $7-8 \mathrm{~g} / \mathrm{dl}$ was $0 \%$. However, it increased significantly when values were lower than $5 \mathrm{~g} / \mathrm{dl}$ : $34 \%$ for $4-5 \mathrm{~g} / \mathrm{dl}, 25 \%$ for $3-4 \mathrm{~g} / \mathrm{dl}, 54 \%$ for $2-3 \mathrm{~g} / \mathrm{dl}$, and $100 \%$ for $1-2 \mathrm{~g} / \mathrm{dl}(\mathrm{n}=7)$. These outcomes have not been studied for patients with very severe chronic anaemia.

\section{CASE DESCRIPTION}

We report the case of a 54-year-old woman admitted at the emergency department with severe fatigue and functional limitation, having been bedridden for the past few months following a 5-year progressive deterioration of general status. In addition to the asthenia, she complained of paraesthesia in all four limbs (without any discernible pattern), episodes of self-limiting lower limb palsy (affecting both legs in an alternating fashion), and frequent falls in the last year which she said were caused by dizziness and lack of balance. She denied any relevant trauma or evident blood loss. Throughout this lengthy period, she had always refused to seek medical attention.

At 49 years of age, she had been diagnosed with gastric cancer (an antral ulcerated lesion with histological features of adenocarcinoma with a solid tubular pattern with isolated signet ring cells, pT3NORO) and underwent total gastrectomy and chemotherapy (8 cycles, capecitabine plus oxaliplatin), without any complications, but was lost to follow-up at the end of the treatment.

Further information concerning the patient's history obtained from her family and her electronic medical records revealed she had experienced severe asthenia after the chemotherapy had ended and had since declined any external support or healthcare assistance. They also confirmed the absence of any evident blood loss. The patient only agreed to go to the emergency department due to the persistence of her son, who contacted the national pre-hospital emergency system. The family did not provide any further explanations besides the refusal of the patient to seek any medical attention.

On physical examination, we found a prostrated, emaciated and severely malnourished individual, showing severe cutaneous and mucosal pallor and severe peripheral oedema. She was somnolent, but easily awaken by verbal stimuli (Glasgow Coma Scale score of 14 due to confusion). Besides a global decrease in muscle strength due to the evident sarcopenia, she showed no other focal neurological deficits, including sensory or proprioceptive dysfunction. Peripheral oxygen saturation was $83 \%$, although she was eupnoeic: arterial blood gas analysis showed $\mathrm{PaO}_{2}$ of $93 \mathrm{mmHg}$ but an unmeasurable $\mathrm{Hb}\left(\mathrm{pH} 7.48, \mathrm{PaCO}_{2} 29 \mathrm{mmHg}, \mathrm{HCO}_{3}-22 \mathrm{mmol} / \mathrm{l}\right.$, lactate $6.74 \mathrm{mmol} / \mathrm{l}$, glucose $107 \mathrm{mg} / \mathrm{dl}$ ). She presented with sinus tachycardia ranging from 90 to $120 \mathrm{bpm}$, an arterial blood pressure of $80 / 44 \mathrm{mmHg}$, and a prolonged capillary refill time. There were no other positive findings on examination.

Laboratory studies on admission (Table 1) showed extreme macrocytic anaemia (Hb of 1.7 g/dl, meancorpuscular volume (MCV) of $121.4 \mathrm{fl}$ and haematocrit of 5.1\%), signs of haemolysis (high indirect bilirubin of $1.15 \mathrm{mg} / \mathrm{dl}$, remarkably high LDH of 5063 U/l, haptoglobin consumption, and negative Coombs test), thrombocytopenia of $59 \times 10^{9}$ platelets/l, and a normal leucocyte count. Even though blood samples were scarce, upon suspicion of megaloblastic anaemia, the laboratory managed to broaden the blood analysis: vitamin B12 was not measurable (<84 pg/ $\mathrm{ml}$ ), and folic acid deficiency and HIV infection were excluded (Table 1).

The patient was admitted to the ICU and a slow correction of the anaemia was started with 2 units of packed RBC, parenteral correction of vitamin B12 deficiency (1 mg once daily) and oral supplementation with folic acid ( $5 \mathrm{mg}$ once daily). Ultrasonography and thoraco-abdominal computed tomography (CT) showed generalized subcutaneous oedema, and mild pleural and pericardial effusions, but no other findings or signs of cancer relapse. A cerebral CT scan excluded intracranial lesions.

Haemodynamic stability was achieved without the need for more blood products, and there was sustained haematological improvement with the described strategy. Platelet levels reached a minimum of $28 \times 10^{9} / /$ on day 3 but started to improve on day 4 and were within the normal range on day 5 . On the 5 th day of hospitalization, haemoglobin $(\mathrm{Hb})$ was $8.5 \mathrm{~g} / \mathrm{dl}$, haemolysis markers were steadily decreasing, and the patient's symptoms were improving, so she was transferred to the medical ward.

She received nutritional and psychiatric evaluation, and the treatment plan was adjusted. Six days later, she was discharged home for outpatient management.

On patient follow-up at 3 and 5 months, she showed normal haematological values, total functional autonomy, and resolution of the peripheral neuropathic symptoms.

\section{DISCUSSION}

The vast majority of vitamin B12 uptake in the gastrointestinal tract depends on its binding with the intrinsic factor produced by gastric parietal cells and its absorption in the distal ileum. Conditions compromising nutritional intake and diseases causing dysfunction of gastric parietal cells and the associated absence of intrinsic factor, or dysfunction of the distal ileum, will result in B12 deficiency as the body's stores start to become depleted ${ }^{[5]}$. Patients may present with a macrocytic anaemia (macrocytic red cells, anisocytosis, macroovalocytes, which were first described in 1855 by Addison ${ }^{[6]}$ ), leukopenia, thrombocytopenia, signs of intravascular haemolysis, elevated levels of 


\begin{tabular}{|c|c|c|c|c|c|c|c|c|}
\hline & Admission & Day 1 & Day 2 & Days 3-4 & Day 5 & Day 6 & 3 Months & 5 Months \\
\hline Haemoglobin (g/dl) & $\downarrow 1.7$ & $\downarrow 4.7$ & $\downarrow 7.6$ & $\downarrow 8.5-8.6$ & $\downarrow 8.2$ & $\downarrow 8.7$ & 14.7 & 14.5 \\
\hline Haematocrit & $\downarrow 5.1 \%$ & $\downarrow 13.4 \%$ & $21 \%$ & & & $27.7 \%$ & $44.4 \%$ & $44.4 \%$ \\
\hline $\operatorname{MCV}(\mathrm{fl})$ & $\uparrow 121.4$ & 92 & 91.1 & & & 92.5 & 83.5 & 85.2 \\
\hline $\mathrm{MCH}(\mathrm{pg})$ & $\uparrow 40.5$ & 32 & 32 & & & 29.5 & 27.6 & 27.8 \\
\hline RDW-SD (fl) & $\uparrow 105$ & 48.5 & 49.3 & & & 54.7 & 44.3 & 41.4 \\
\hline Reticulocytes $\left(\times 10^{12} / \mathrm{I}\right)$ & & $\downarrow 1.45$ & & & 2.84 & & & \\
\hline Leucocytes $\left(\times 10^{9} / \mathrm{I}\right)$ & 4.25 & 4.49 & 5.24 & $\begin{array}{c}2.25- \\
2.33\end{array}$ & 3.12 & 3.84 & 6.39 & 8.99 \\
\hline Neutrophils & 2.76 & & & & & 1.55 & & 4.79 \\
\hline Lymphocytes & 1.4 & & & & & 1.69 & & 3.46 \\
\hline Monocytes & 0.06 & & & & & 0.33 & & 0.41 \\
\hline Eosinophils & 0.01 & & & & & 0.26 & & 0.29 \\
\hline Immature granulocytes & 0.02 & & & & & 0.01 & & \\
\hline Platelets $\left(\times 10^{\circ} / \mathrm{l}\right)$ & $\downarrow 59$ & $\downarrow 38$ & $\downarrow 28$ & $\downarrow 50-121$ & 154 & 218 & 175 & 233 \\
\hline Peripheral blood smear & $\begin{array}{l}\text { Anisocytosis, } \\
\text { poikilocytosis, }\end{array}$ & & & & & & & \\
\hline Hypochromia & 0-2 Schizocytes & & & $\begin{array}{l}\text { Platelet } \\
\text { rouleaux }\end{array}$ & & & & \\
\hline Lactate dehydrogenase (U/I) & $\uparrow 5063$ & $\uparrow 3515$ & $\uparrow 3320$ & & & $\uparrow 1878$ & 216 & 236 \\
\hline Haptoglobin (mg/dl) & $<8$ & & & & & & & \\
\hline Total bilirubin (mg/dl) & $\uparrow 3.7$ & $\uparrow 2.54$ & $\uparrow 3.54$ & & 0.87 & 0.59 & 0.54 & 0.35 \\
\hline Indirect bilirubin (mg/dl) & $\uparrow 1.15$ & & 0.83 & & 0.27 & & & 0.06 \\
\hline Coombs tests & Negative & & & & & & & \\
\hline HIV $1+2$ antigen and antibody & Negative & & & & & & & \\
\hline Folic acid (ng/dl) & $\downarrow 7.8$ & & & & & & & $>20$ \\
\hline Vitamin B12 (pg/ml) & $\downarrow<83$ & & & & $>2000$ & & 1412 & 1361 \\
\hline Iron ( $\mu \mathrm{g} / \mathrm{dl})$ & 190 & & & & & & 112 & 70 \\
\hline Transferrin (ng/dl) & 150 & & & & & & 297 & 295 \\
\hline Transferrin saturation & $\uparrow 90 \%$ & & & & & & $27 \%$ & $17 \%$ \\
\hline Ferritin (ng/ml) & 207 & & & & & & 61.3 & \\
\hline
\end{tabular}




\begin{tabular}{|c|c|c|c|c|c|c|c|c|}
\hline & Admission & Day 1 & Day 2 & Days 3-4 & Day 5 & Day 6 & 3 Months & 5 Months \\
\hline Aspartate transaminase (U/I) & $\uparrow 175$ & $\uparrow 189$ & $\uparrow 173$ & & 27 & 34 & 27 & 24 \\
\hline Alanine transaminase (U/I) & $\uparrow 187$ & $\uparrow 258$ & $\uparrow 290$ & & 81 & 71 & 24 & 26 \\
\hline Gamma-glutamyl transferase (U/I) & 22 & 24 & 21 & & 19 & 20 & 20 & 19 \\
\hline Alkaline phosphatase (U/I) & 59 & 55 & & & 46 & & 163 & 191 \\
\hline C-reactive protein (mg/l) & 6 & & & & & 0.8 & & \\
\hline Sedimentation rate $\left(\mathrm{mm} / 1^{\text {st }} \mathrm{h}\right)$ & & & & & & 6 & & \\
\hline Total protein (g/l) & $\downarrow 51.8$ & & & & & & 75.2 & \\
\hline Albumin (g/l) & $\downarrow 33.4$ & $\downarrow 26.3$ & & & $\downarrow 29$ & & 44.9 & \\
\hline Serum protein electrophoresis & & & & & & & Normal & \\
\hline Uric acid (mg/dl) & 9.3 & & & & & & 4.3 & \\
\hline Urea (mg/dl) & 67 & & & & & & 30 & \\
\hline Creatinine (mg/dl) & 1.03 & & & & & & 0.59 & \\
\hline Troponin I - hs (ng/l) & 8.6 & & & & & & & \\
\hline Brain natriuretic peptide (pg/ml) & 627 & & & & & & 27 & \\
\hline Thyroid-stimulating hormone (IU/ml) & 2.34 & & & & & & 1.66 & \\
\hline \multicolumn{9}{|l|}{ Classic gastric tumour markers } \\
\hline CEA (ng/ml) & & & & & & & & 1.7 \\
\hline CA $19.9(\mathrm{U} / \mathrm{ml})$ & & & & & & & & 7 \\
\hline CA $72.4(\mathrm{U} / \mathrm{ml})$ & & & & & & & & 0.5 \\
\hline
\end{tabular}

hs, high sensitivity; MCH, mean corpuscular haemoglobin; MCV, mean corpuscular volume; RDW-SD, red cell distribution width-standard deviation.

Table 1 Laboratory results throughout patient follow-up

homocysteine and methylmalonic acid, and a wide spectrum of neurological symptoms ranging from altered mental status and cognitive defects, to myelopathy and peripheral neuropathy ${ }^{[5]}$.

The discovery of vitamin B12 and its biochemical role in humans has spanned two centuries of breakthroughs, clinical reports and pivotal studies ${ }^{[6]}$, leading to two different Nobel Prizes (Medicine in $1934{ }^{[7,8]}$ and Chemistry in 1964). Consequently, vitamin B12 deficiency can now be easily diagnosed and treated ${ }^{[6]}$. Even though dietary deficiency and pernicious anaemia are frequently found in the general population, and the number of patients surviving gastrointestinal disorders and surgery has increased, extreme insufficiency presenting as life-threatening anaemia, pancytopenia or myelopathy, is far less common than in the past.

In 1947, MacDonald et al. had already recognized the development of a macrocytic anaemia in gastrectomized patients, "if they live long enough", and its morphological similarity to the "Addisonian anaemia" [9]. In 1966, Williams et al. demonstrated the benefit of permanent vitamin B12 supplementation after gastrectomy, regardless of the presence of haematological signs ${ }^{[10]}$. Currently, it is standard practice to guarantee lifelong adequate iron, B12 and folate monitoring in this set of patients. 
In our patient's case, the loss to follow-up after her gastrectomy hindered the appropriate follow-up and supplementation. Such an extremely low haemoglobin level only seems possible if there has been a slow and progressive depletion of B12 stores along with physiological and functional adaptation to the progressive anaemia. Active bleeding was excluded as the patient reported no gastrointestinal or genitourinary blood loss, a CT scan showed no signs of internal bleeding or recurrence of oncological disease, and all haematological parameters steadily improved under treatment.

While we are aware of several anecdotal unpublished reports, we only found 23 published reports of patients with similar anaemia (haemoglobin levels $<2 \mathrm{~g} / \mathrm{dl}$ ). The lowest value recorded in a patient who survived was $0.4 \mathrm{~g} / \mathrm{dl}$. Our case seems to be the third reported of a patient surviving what seems to be extreme chronic anaemia (Appendix Table 1) ${ }^{[11,12]}$.

In the absence of haemorrhagic shock, the standard therapy in these patients was treatment with a restrictive transfusion strategy, supporting haemodynamic and symptom stability, as transfusion complications such as ischaemic stroke, reversible cerebral vasoconstriction syndrome and hyperhaemolysis can occur. This is similar to the treatment provided to our patient, who recovered without any sequelae or complications.

\section{CONCLUSION}

Reports of patients with extreme anaemia $(\mathrm{Hb}<2 \mathrm{~g} / \mathrm{dl})$ are now very rare after the advent of blood transfusion medicine in the second half of the 20th century, along with wider access to better healthcare, improved management of critical situations and bleeding control, the implementation of enteral and parenteral supplementation with iron, folate and vitamin B12, and active anaemia screening in the general population.

As reported anecdotally in the literature, this type of severe anaemia only seems to be possible if there is slow progressive depletion of vitamin B12 stores in the absence of adequate nutrition. Adherence to treatment and medical advice is essential in patients who will also require life-long follow-up.

\section{REFERENCES}

1. Roubinian NH, Murphy EL, Mark DG, Triulzi DJ, Carson JL, Lee C, et al. Long-term outcomes among patients discharged from the hospital with moderate anemia: a retrospective cohort study. Ann Intern Med 2019;170(2):81-89.

2. NICE. Blood transfusion, NICE guideline [NG24] Published date: 18 November 2015. Available from https://www.nice.org.uk/guidance/ng24

3. Mueller MM, Van Remoortel H, Meybohm P, Aranko K, Aubron C, Burger R, et al. Patient blood management: recommendations from the 2018 Frankfurt Consensus Conference. JAMA 2019;321(10):983-997.

4. Carson JL, Noveck H, Berlin JA, Gould SA. Mortality and morbidity in patients with very low postoperative Hb levels who decline blood transfusion. Transfusion 2002;42(7):812818.

5. Stabler SP. Vitamin B12 deficiency. N Engl J Med 2013;368(2):149-160.

6. Scott JM, Molloy AM. The discovery of vitamin B12. Ann Nutr Metab 2012;61:239-245.

7. Minot GR, Murphy WP. Treatment of pernicious anemia by a special diet. J Am Med Assoc 1926;87(7):470-476.

8. Castle WB, Ham TH. Landmark article Oct 31, 1936: Observations on the etiologic relationship of achylia gastrica to pernicious anemia. V. Further evidence for the essential participation of extrinsic factor in hematopoietic responses to mixtures of beef muscle and gastric juice and to hog stomach mucosa. By W.B. Castle and T.H. Ham. JAMA 1984;251(4):514-521.

9. MacDonald RM, Ingelfinger FJ, Belding HW. Late effects of total gastrectomy in man. N Engl J Med 1947;237(24):887-896.

10. Williams JA, Baume PE, Meynell MJ. Partial gastrectomy: the value of permanent vitamin-B-12 therapy. Lancet 1966;1(7433):342-344.

11. Lindgren A, Lasson A. [Hb 17g/1! The patient survived without obvious sequelae. A case report of extreme pernicious anemia]. Lakartidningen 2008;105(43):3015-3017.

12. Shiraishi W, Une H, Iwanaga Y, Yamamoto A. A case of post-transfusion posterior reversible encephalopathy syndrome with cerebral hemorrhage that may be associated with fat-soluble vitamin deficiency. Clin Neurol 2014;54(6):518-521. 


\begin{tabular}{|c|c|c|c|c|c|c|c|}
\hline & Year & Age, gender & Diagnosis & Hb nadir & Treatment & Outcome & Notes \\
\hline Biesma et al. [1] & 1997 & 21 y, M & $\begin{array}{l}\text { Haemolytic anaemia } \\
\text { secondary to B19 } \\
\text { parvovirus infection in a } \\
\text { sickle-cell } \beta \text {-thalassemia } \\
\text { patient }\end{array}$ & $1.13 \mathrm{~g} / \mathrm{dl}$ & RBC transfusion & Improved & \\
\hline Yamashita et al. [3] & 1999 & $42 y, F$ & Uterine myoma & $1.2 \mathrm{~g} / \mathrm{dl}$ & $\begin{array}{l}\text { RBC transfusion } \\
\text { Hysterectomy }\end{array}$ & Improved & \\
\hline Imaizumi et al. [4] & 1999 & $61 \mathrm{y}, \mathrm{M}$ & $\begin{array}{l}\text { Haematuria due to } \\
\text { bladder tumour }\end{array}$ & $1.8 \mathrm{~g} / \mathrm{dl}$ & RPC transfusion & Improved & \\
\hline Heo et al. [5] & 2003 & $47 y, F$ & Aplastic anaemia & $1.5 \mathrm{~g} / \mathrm{dl}$ & RBC transfusion & Improved & $\begin{array}{l}\text { Complicated after RBC } \\
\text { transfusion with RCVS } \\
\text { and PRES }\end{array}$ \\
\hline Lindgren et al. [6] & 2008 & $?$ & Pernicious anaemia & $1.7 \mathrm{~g} / \mathrm{dl}$ & Unknown & Improved & $\begin{array}{l}\text { Article in Swedish, not } \\
\text { available }\end{array}$ \\
\hline Schuettpelz et al. [7] & 2009 & $6 y, F$ & $\begin{array}{l}\text { Ceftriaxone-induced } \\
\text { haemolytic anaemia in a } \\
\text { sickle cell disease patient }\end{array}$ & $0.4 \mathrm{~g} / \mathrm{dl}$ & $\begin{array}{l}\text { RBC transfusion } \\
\text { Corticosteroids } \\
\text { and IVIG } \\
\text { Plasmapheresis }\end{array}$ & Improved & $\begin{array}{l}\text { Complicated afterwards } \\
\text { with ischaemic stroke. } \\
\text { On discharge was under } \\
\text { neurorehabilitation and } \\
\text { improving }\end{array}$ \\
\hline Kunzmann et al. [8] & 2010 & $23 y, F$ & $\begin{array}{l}\text { Piperacillin-induced } \\
\text { haemolytic anaemia }\end{array}$ & $1.6 \mathrm{~g} / \mathrm{dl}$ & $\begin{array}{l}\text { RBC transfusion } \\
\text { Corticosteroids }\end{array}$ & Improved & \\
\hline Dai et al. [9] & 2010 & 53 y, M & $\begin{array}{l}\text { Haemorrhagic shock due } \\
\text { to multiple stab wounds }\end{array}$ & $0.7 \mathrm{~g} / \mathrm{dl}$ & $\begin{array}{l}\text { RBC transfusion } \\
\text { Balanced } \\
\text { salt solution } \\
\text { and plasma } \\
\text { substitutes }\end{array}$ & Improved & $\begin{array}{l}\text { Extreme haemodilution } \\
\text { in which appropriately } \\
\text { crossmatched blood was } \\
\text { not available }\end{array}$ \\
\hline De Prost et al. [10] & 2012 & 27 y, M & $\begin{array}{l}\text { Acute splenic } \\
\text { sequestration in a sickle } \\
\text { cell disease patient }\end{array}$ & $1.7 \mathrm{~g} / \mathrm{dl}$ & $\begin{array}{l}\text { RBC transfusion } \\
\text { Splenectomy }\end{array}$ & Improved & \\
\hline Rovira et al. [11] & 2013 & $26 y, F$ & $\begin{array}{l}\text { Immune haemolytic } \\
\text { anaemia following } \\
\text { allogeneic stem cell } \\
\text { transplantation }\end{array}$ & $<2 \mathrm{~g} / \mathrm{dl}$ & $\begin{array}{l}\text { RBC transfusion } \\
\text { Corticosteroids } \\
\text { and IVIG } \\
\text { Splenectomy }\end{array}$ & Death & $\begin{array}{l}\text { No access to lowest } \mathrm{Hb} \\
\text { level - values derived from } \\
\text { graphic interpretation }\end{array}$ \\
\hline Graffeo et al. [12] & 2013 & $39 y, F$ & $\begin{array}{l}\text { Placental abruption } \\
\text { complicated with } \\
\text { haemorrhagic shock } \\
\text { and disseminated } \\
\text { intravascular coagulation }\end{array}$ & $1.9 \mathrm{~g} / \mathrm{dl}$ & $\begin{array}{l}\text { Caesarean } \\
\text { delivery } \\
\text { EPO } \\
\text { Hyperbaric } \\
\text { oxygenation }\end{array}$ & Improved & $\begin{array}{l}\text { Refused blood } \\
\text { components }\end{array}$ \\
\hline Odronic et al. [13] & 2014 & $53 y, F$ & $\begin{array}{l}\text { Cocaine-induced } \\
\text { microangiopathic } \\
\text { haemolytic anaemia }\end{array}$ & $1.8 \mathrm{~g} / \mathrm{dl}$ & $\begin{array}{l}\text { RBC transfusion } \\
\text { Plasmapheresis }\end{array}$ & Improved & \\
\hline
\end{tabular}




\begin{tabular}{|c|c|c|c|c|c|c|c|}
\hline & Year & Age, gender & Diagnosis & Hb nadir & Treatment & Outcome & Notes \\
\hline Yeykal et al. [14] & 2014 & 43 y, M & $\begin{array}{l}\text { GI bleeding secondary to } \\
\text { C. difficile colitis }\end{array}$ & $1.8 \mathrm{~g} / \mathrm{dl}$ & $\begin{array}{l}\text { EPO, iron } \\
\text { and folate } \\
\text { supplements } \\
\text { Aminocaproic } \\
\text { acid, FFP and } \\
\text { VIIla coagulation } \\
\text { factor } \\
\text { IVIG } \\
\text { Surgery }\end{array}$ & Improved & $\begin{array}{l}\text { Refused blood } \\
\text { components }\end{array}$ \\
\hline De Araújo et al. [15] & 2014 & $27 y, F$ & $\begin{array}{l}\text { Haemorrhagic } \\
\text { complications during } \\
\text { surgical correction of } \\
\text { scoliosis }\end{array}$ & $1.4 \mathrm{~g} / \mathrm{dl}$ & $\begin{array}{l}\text { Normovolaemic } \\
\text { haemodilution } \\
\text { Hyperoxic } \\
\text { ventilation } \\
\text { EPO, iron, } \\
\text { vitamin B12 } \\
\text { and folate } \\
\text { supplements }\end{array}$ & Improved & $\begin{array}{l}\text { Refused blood } \\
\text { components }\end{array}$ \\
\hline \multirow[t]{2}{*}{ Dou et al. [16] } & 2014 & $50 y, F$ & $\begin{array}{l}\text { Menorrhagia (uterine } \\
\text { leiomyoma and } \\
\text { adenomyosis) }\end{array}$ & $1.5 \mathrm{~g} / \mathrm{dl}$ & RBC transfusion & Improved & $\begin{array}{l}\text { Complicated after RBC } \\
\text { transfusion with PRES }\end{array}$ \\
\hline & 2014 & $46 y, F$ & $\begin{array}{l}\text { Menometrorrhagia } \\
\text { (uterine leiomyoma) }\end{array}$ & $1.4 \mathrm{~g} / \mathrm{dl}$ & & & \\
\hline Shiraishi et al. [17] & 2014 & $36 y, F$ & $\begin{array}{l}\text { Severe malnutrition due } \\
\text { to peculiar eating habits }\end{array}$ & $1.4 \mathrm{~g} / \mathrm{dl}$ & $\begin{array}{l}\text { RBC transfusion } \\
\text { Iron, vitamin } \\
\text { B complex } \\
\text { and folate } \\
\text { supplements }\end{array}$ & Improved & $\begin{array}{l}\text { Complicated after RBC } \\
\text { transfusion with PRES } \\
\text { and multiple intracranial } \\
\text { haemorrhages and } \\
\text { visual disturbances (also } \\
\text { due to vitamin K and A } \\
\text { deficiency) }\end{array}$ \\
\hline Singh et al. [18] & 2015 & $36 y, F$ & $\begin{array}{l}\text { Menorrhagia (uterine } \\
\text { fibroid) }\end{array}$ & $1.7 \mathrm{~g} / \mathrm{dl}$ & RBC transfusion & Improved & $\begin{array}{l}\text { Complicated after } \\
\text { RBC transfusion with } \\
\text { development of PRES }\end{array}$ \\
\hline Lim et al. [19] & 2015 & $68 \mathrm{y}, \mathrm{F}$ & $\begin{array}{l}\text { Chinese traditional } \\
\text { medicine consisting of } \\
\text { frequent bloodletting } \\
\text { ('Sahyeol') in a patient } \\
\text { with schizoid personality } \\
\text { disorder }\end{array}$ & $1.4 \mathrm{~g} / \mathrm{dl}$ & $\begin{array}{l}\text { RBC transfusion } \\
\text { Iron supplement }\end{array}$ & Improved & $\begin{array}{l}1 \text { Year after, she returned } \\
\text { to bloodletting habits and } \\
\text { was admitted again with } \\
\text { values of } \mathrm{Hb} \text { of } 1.5 \mathrm{~g} / \mathrm{dl} \text { - } \\
\text { after she was transferred } \\
\text { to a neuropsychiatry ward }\end{array}$ \\
\hline Chojnowski et al. [20] & 2016 & 22 y, M & $\begin{array}{l}\text { Acute pre-T-lymphoblastic } \\
\text { leukaemia patient } \\
\text { undergoing induction and } \\
\text { consolidation therapy }\end{array}$ & $1.3 \mathrm{~g} / \mathrm{dl}$ & $\begin{array}{l}\text { EPO, iron } \\
\text { and folate } \\
\text { supplements } \\
\text { Total parenteral } \\
\text { nutrition }\end{array}$ & Improved & $\begin{array}{l}\text { Refused blood } \\
\text { components }\end{array}$ \\
\hline Schmitt et al. [21] & 2016 & $34 \mathrm{y}, \mathrm{M}$ & Colon adenocarcinoma & $1.8 \mathrm{~g} / \mathrm{dl}$ & $\begin{array}{l}\text { RBC transfusion } \\
\text { Iron supplement }\end{array}$ & Improved & \\
\hline Bienz et al. [22] & 2020 & $\mathrm{NB}, \mathrm{M}$ & $\begin{array}{l}\text { Fetomaternal } \\
\text { haemorrhage }\end{array}$ & $1.2 \mathrm{~g} / \mathrm{dl}$ & RBC transfusion & Improved & \\
\hline
\end{tabular}

The only two cases of extreme chronic anaemia are highlighted (in bold). EPO, erythropoietin; F, female; FFP, fresh frozen plasma; Hb, haemoglobin; IVIG, intravenous immunoglobulin; M, male; NB, new-born; PRES, posterior reversible encephalopathy syndrome; RBC, red blood cells; RCVS, reversible cerebral vasoconstriction syndrome; y, years. 


\section{APPENDIX REFERENCES}

1. Biesma DH, Nieuwenhuis HK. Life-threatening anaemia caused by B19 parvovirus infection in a non-immunocompromised patient. Neth J Med 1997;50(2):81-84.

2. Zollinger A, Hager P, Singer T, Friedl HP, Pasch T, Spahn DR. Extreme hemodilution due to massive blood loss in tumor surgery. Anesthesiology 1997;87(4):985-987.

3. Yamashita S, Matsumiya N, Fujii T, Yamaguchi H. A case of progressive congestive heart failure secondary to severe anemia in a patient presenting with uterine hemorrhage. Resuscitation 1999;42(1):69-72.

4. Imaizumi T, Yagi E, Ushijima K, Suzuki K, Terasaki H, Imaizumi T. A patient with a preoperative hemoglobin concentration of $1.8 \mathrm{~g} / \mathrm{dL}$ : how was the life-threatening anemia tolerated without any intensive care? J Anesth 1999;13(2):125-126.

5. Heo K, Park SA, Lee JY, Lee BI, Lee SK. Post-transfusion posterior leukoencephalopathy with cytotoxic and vasogenic edema precipitated by vasospasm. Cerebrovasc Dis 2003;15(3):230-233.

6. Lindgren A, Lasson A. [Hb 17g/1! The patient survived without obvious sequelae. A case report of extreme pernicious anemia]. Lakartidningen 2008;105(43):3015-3017.

7. Schuettpelz LG, Behrens D, Goldsmith MI, Druley TE. Severe ceftriaxone-induced hemolysis complicated by diffuse cerebral ischemia in a child with sickle cell disease. J Pediatr Hematol Oncol 2009;31(11):870-872.

8. Kunzmann S, Thomas W, Mayer B, Kuhn S, Hebestreit H. Immune-mediated severe hemolytic crisis with a hemoglobin level of $1.6 \mathrm{~g} / \mathrm{dl}$ caused by anti-piperacillin antibodies in a patient with cystic fibrosis. Infection 2010;38(2):131-134.

9. Dai J, Tu W, Yang Z, Lin R. Intraoperative management of extreme hemodilution in a patient with a severed axillary artery. Anesth Analg 2010;111(5):1204-1206.

10. de Prost N, Bartolucci P, Boroli F, Moroch J, Galacteros F, Brun-Buisson C, et al. Extreme acute anemia in an adult sickle cell disease patient: look at the spleen. Intensive Care Med 2012;38:337-338.

11. Rovira J, Cid J, Gutierrez-Garcia G, Pereira A, Fernandez-Aviles F, Rosinol L, et al. Fatal immune hemolytic anemia following allogeneic stem cell transplantation: report of 2 cases and review of literature. Transfus Med Rev 2013;27(3):166-170.

12. Graffeo C, Dishong W. Severe blood loss anemia in a Jehovah's Witness treated with adjunctive hyperbaric oxygen therapy. Am J Emerg Med 2013;31(4):756.e3-4.

13. Odronic S, Quraishy NJ, Manroa P, Kier Y, Koo A, Figueroa P, et al. Cocaine-induced microangiopathic hemolytic anemia mimicking idiopathic thrombotic thrombocytopenic purpura: a case report and review of the literature. J Clin Apher 2014;29(5):284-289.

14. Yeykal JM, Stausmire JM, Ahmed MY, Pai A. Right hemicolectomy in a severely anemic Jehovah's witness patient with an extremely low preoperative hemoglobin level and the decision to operate. J Am Osteopath Assoc 2014;114(12):930-935.

15. De Araújo Azi LMT, Lopes FM, Garcia LV. Postoperative management of severe acute anemia in a Jehovah's Witness. Transfusion 2014;54(4):1153-1157.

16. Dou YH, Fuh JL, Chen SP, Wang SJ. Reversible cerebral vasoconstriction syndrome after blood transfusion. Headache 2014;54(4):736-744.

17. Shiraishi W, Une H, Iwanaga Y, Yamamoto A. A case of post-transfusion posterior reversible encephalopathy syndrome with cerebral hemorrhage that may be associated with fat-soluble vitamin deficiency. Clin Neurol 2014;54(6):518-521.

18. Singh K, Gupta R, Kamal H, Silvestri NJ, Wolfe GI. Posterior reversible encephalopathy syndrome secondary to blood transfusion. J Clin Neurosci 2015;22(3):592-594.

19. Lim W-H, Kim S-H, Kim H-L, Kim K-H, Na SH, Lee H-J, et al. Recurrent acute decompensated heart failure owing to severe iron deficiency anemia caused by inappropriate habitual bloodletting. J Cardiovasc Ultrasound 2015;23(4):253-256.

20. Chojnowski K, Janus A, Bliźniewska K, Robak M, Treliński J. Long-lasting extreme anemia during the therapy of acute lymphoblastic leukemia in a Jehovah's Witness patient. Transfusion 2016;56(10):2438-2442.

21. Schmitt RE, Buckley CJ. Extreme anemia (hemoglobin 1.8 g/dL) secondary to colon cancer. Proc (Bayl Univ Med Cent) 2016;29(4):393-394.

22. Bienz MN, Hsia C, Waye JS, Bode M, Solh Z. A novel human $\beta$-globin gene variant [Hb London-Ontario, HBB: c.332T>G] is associated with transfusion-dependent anemia in a patient with a hemoglobin electrophoresis pattern consistent with $\beta$-thalassemia trait. Hemoglobin 2019;43(2):129-131. 